\title{
ecancermedicalscience
Locally advanced breast cancer in young women in Latin America
}

\author{
Cynthia Villarreal-Garza',2,3, Edna A Lopez-Martinez ${ }^{1,3}$, Jose Felipe Muñoz-Lozano ${ }^{1,3}$, Karla Unger-Saldaña ${ }^{4}$ \\ ${ }^{1}$ Breast Cancer Center, TecSalud, Tecnologico de Monterrey, Monterrey 66278, Mexico \\ ${ }^{2}$ Research and Breast Cancer Department, Mexican National Cancer Institute, Mexico City 14080, Mexico \\ ${ }^{3}$ Joven and Fuerte Program for Young Women with Breast Cancer, Mexico City 03720, Mexico \\ ${ }^{4}$ CONACYT fellow—Epidemiology Unit, Mexican National Cancer Institute, Mexico City 14080, Mexico \\ Correspondence to: Cynthia Villarreal-Garza. Email: cynthia.villarreal@tecsalud.mx
}

\begin{abstract}
The purpose of this review is to organise, summarise and critically assess existing knowledge on locally advanced breast cancer (LABC) among young women in Latin America. We discuss the most relevant findings in six sections: 1) epidemiology of breast cancer in young women in Latin America; 2) being young as a factor for worse prognosis; 3) LABC in young women in the region; 4) aggressive tumour behaviour among young women; 5) delays in diagnosis and treatment and 6) burden of advanced disease. We point out the need to dedicate resources to enhance earlier diagnosis and prompt referrals of young women with breast cancer; promote research regarding prevalence, biologic characteristics, outcomes and reasons for diagnosis and treatment delays for this age group; and finally, implement supportive care programmes as a means of improving patients and their families' well-being. The recognition of the current standpoint of breast cancer in young patients across the continent should shed some light on the importance of this pressing matter.
\end{abstract}

Keywords: young, breast cancer, locally advanced, Latin America, delay

Published: 22/01/2019

Received: 01/05/2018

ecancer 2019, 13:894 https://doi.org/10.3332/ecancer.2019.894

Copyright: (c) the authors; licensee ecancermedicalscience. This is an Open Access article distributed under the terms of the Creative Commons Attribution License (http://creativecommons.org/licenses/by/3.0), which permits unrestricted use, distribution, and reproduction in any medium, provided the original work is properly cited. 


\section{Introduction}

Breast cancer $(\mathrm{BC})$ is the leading cause of cancer-related death and disability among young women in Latin America [1-3]. As 13\% of BC deaths occur in women aged < 45 years, this represents a significant burden across the region [4]. Overall, young women with breast cancer (YWBC) are often diagnosed in late disease stages $[5,6]$ and, thus, undergo more aggressive treatment regimens with considerable morbidity, socio-economic repercussions and poor outcomes [7, 8]. Furthermore, the prognosis of YWBC in Latin America is worse than that in developed countries, mainly due to late disease stage at presentation, especially when coupled with inequities in access to care and inadequate health system capacity for achieving timely diagnosis and treatment [1]. Thus, BC occurring at younger ages represents an extra challenge in terms of prevention, early detection, treatment and survivorship care in this region [9].

The purpose of this review is to organise, summarise and critically assess existing knowledge on locally advanced breast cancer (LABC) among young women in Latin America. The recognition of the current standpoint of BC in young patients across the continent should shed some light on the importance of this pressing matter.

An extensive literature search was conducted in the following electronic databases: PubMed, Cochrane and SciELO. Also, records of previous relevant annual cancer conferences, such as the American Society of Clinical Oncology Annual Meeting, the European Society of Medical Oncology Annual Congress and the San Antonio Breast Cancer Symposium were consulted. The following keywords were used in various combinations, both in English and Spanish: locally advanced breast cancer, LABC, locally advanced disease, stage III, stage IIB, young, < 40 years, < 35 years, < 30 years, epidemiology, delay, time intervals, intervals of care, diagnosis interval, health system interval, health provider interval, Latin America, Latin American, low and middle-income countries (LMICs), LMICs, Central America, South America and the name of each country in Latin America. We included manuscripts or abstracts published between 1992 and 2017 . Additionally, reference lists of studies included in this review were hand-searched for relevant publications.

Two reviewers screened the titles and abstracts of all records for relevance and assessed potential ones for inclusion. Disagreements were resolved by discussion with a third reviewer. Studies that reported young women diagnosed with LABC, stage II or stage III BC, or that were primarily aimed at describing or analysing BC in Latin American countries were included in this analysis. One hundred and ninety-nine manuscripts/abstracts were identified through the electronic database search and six through manual searches of references in relevant studies. 158/205 were excluded after reviewing the title and abstract because they did not address the research topics and $47 / 205$ were selected for full-text review. Of these, seven additional papers were excluded because they did not contain relevant information for this research. Forty manuscripts/abstracts were included in the final analysis.

One of the limitations faced during the information search was the scarcity of data addressing LABC in Latin America. Thus, the information included in this critical review comprises results from individual institutions, mainly from Mexico and Brazil, which might compromise the generalisability of the findings. Moreover, due to the non-standard definitions of young and locally advanced disease, manuscripts and abstracts reviewed reported heterogeneous evidence, which made data analysis challenging.

In this critical review, relevant information is presented in the following sections: 1) epidemiology of BC in young women in Latin America; 2) being young as a factor for worse prognosis; 3) LABC in young women in the region; 4) aggressive tumour behaviour among young women; 5) delays in diagnosis and treatment and 6) burden of advanced disease.

\section{Epidemiology of breast cancer in young women in Latin America}

$\mathrm{BC}$ in young women is a significant public health issue, especially in Latin American countries, where the proportion of BC in young patients aged $<40$ and $<44$ years reaches up to $11 \%$ and $20 \%$, respectively, a higher proportion compared to the incidence rates of developed countries such as USA and Canada, which approximates $5 \%$ and $11 \%$ in each age group (Figure 1) [4]. A possible contributor to this phenomenon is the younger age distribution in Latin American populations [9]. However, it has been reported that up to one-third of the incidence of $\mathrm{BC}$ cases in young women might not be explained by the younger age distribution in Latin American countries, as demographic, socioeconomic, genetic and lifestyle-related risk factors could also be important contributors [9].

Several studies in Latin American countries have assessed the prevalence of BC among young patients and found a greater burden of disease than expected. In 2001, a Mexican study reported that the prevalence of patients < 40 years was 16.4\% [10]. As for Brazil, a cohort of 59,317 patients reported that the prevalence of patients ages 18-38 years was 10.9\% [11]. The Bahamas is another notable example reporting a $12 \%$ prevalence of young patients in the year 2011 [12]. 


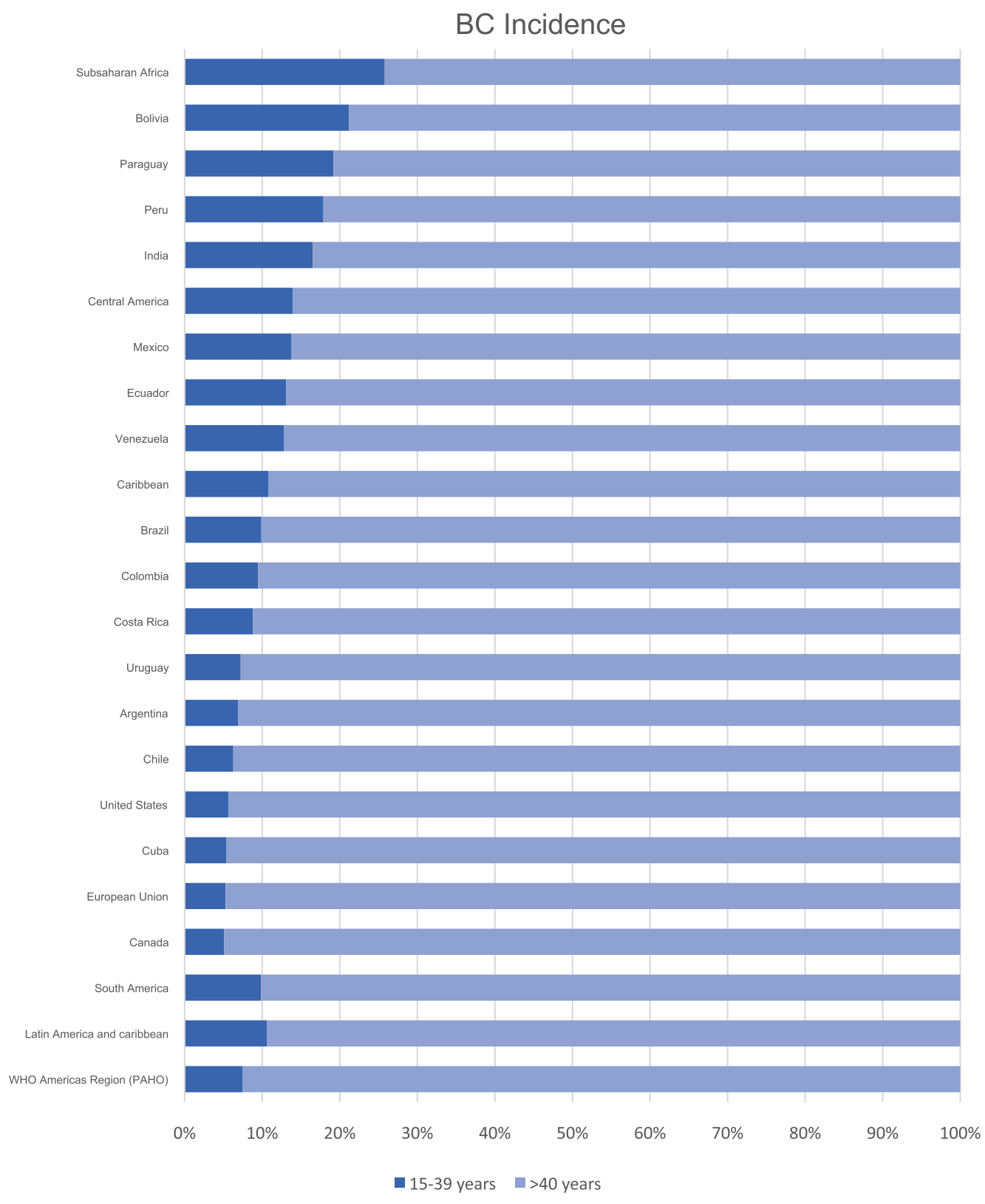

Figure 1. BC incidence by age group (15-39 versus $\geq 40$ years) according to GLOBOCAN 2012 [4].

Notably, BC is one of the main causes of death in young women $<40$ years across Latin America, accounting for $7 \%$ of all BC deaths in women [4], with the highest rates seen in Venezuela, Bolivia, Peru and Mexico, with $8 \%, 9 \%, 9 \%$ and $11 \%$, respectively [4]. Various studies in Latin American countries have addressed this unmet growing healthcare concern. For example, in a descriptive study of mortality due to cancer in women in Sao Paulo, Brazil, the main cause of death for the group aged 30-49 years was BC [13]. Likewise, according to the Mexican population registry Instituto Nacional de Estadistica y Geografia (INEGI), BC is the main cause of cancer death in women aged 20 and older [4, 14]. Furthermore, another study from Brazil has shown an increasing trend in BC mortality in women aged 20-49 years [15]. 


\section{Being young as a factor for worse prognosis in Latin America}

Studies in Latin American countries have confirmed that being young is an independent risk factor for recurrence and worse survival rates. In a study from Chile that compared survival rates at 5 years between patients $\leq 40$ and $\geq 70$ years old, with stage I to III disease, it was concluded that young patients had a higher recurrence rate than older women $(25.8 \%$ versus $11.7 \%)$ but had lower mortality $(17.3 \%$ versus $29.4 \%$ ), potentially due to lower chemotherapy use in the elderly population with high-risk tumours [16]. Similarly, in a historical cohort of women with BC, diagnosed between 2000 and 2002 in Brazil, age < 30 years was significantly associated with increased risk of death (hazard ratio $(\mathrm{HR})=3.09$; 95\% confidence interval $(\mathrm{Cl}): 1.25-7.67)$ [17]. Another Mexican study revealed that young patients had poorer disease-free survival (DFS) and overall survival (OS) compared to those $>40$ years $(75.6 \%$ versus $85.7 \%, p<0.001$ and $78.6 \%$ versus $83.4 \%, p=0.012$, respectively) [18]. In an observational report from the same group in Mexico, patients with BC undergoing neoadjuvant treatment were evaluated, and while young women achieved higher pathologic complete response rates, the recurrence-free survival interval was shorter for young patients with and without pathologic complete response, compared with their older counterparts [19]. Finally, in a descriptive study of 323 cases of stage III BC treated in a referral hospital in Mexico, in which $60 \%$ of patients were < 50 years, 5 -year DFS was only $35 \%$ [20].

\section{Locally advanced breast cancer in young women in Latin America}

Although there is scarce information addressing this issue and cancer registries in the region are lacking, available data show a high prevalence of advanced disease in Latin America. Table 1 summarises the most relevant data regarding YWBC and LABC in Latin American countries.

Studies from Mexico have shown a prevalence of $L A B C$ in young women that ranges from $43.5 \%$ to $68 \%$. The largest BC retrospective cohort conducted at the 'Instituto Nacional de Cancerologia (INCan)' in Mexico City, including 4315 BC patients, reported a statistically significant higher prevalence of larger tumours, positive lymph node disease and stage III BC in young women $\leq 40$ years when compared with older patients (29\%, 39.5\% and $43.5 \%$ versus $17 \%, 29.9 \%$ and $34.9 \%$, respectively). For patients without metastatic disease at diagnosis, 5 -year DFS was lower in women $\leq 40$ years compared with those $>40$ years $(75.6 \%$ versus $85.7 \%, p<0.001)$. This difference was mainly attributable to a significantly lower 5-year DFS in younger women with stage III tumours $(p=0.01)$ [18]. An additional retrospective cohort conducted at INCan that involved 320 YWBC $\leq 42$ years old reported that $67.5 \%$ of patients were diagnosed with locally advanced disease [21].

Additional studies conducted in Mexico have confirmed the high prevalence of LABC in young women. The previously mentioned study that involved 323 patients diagnosed with stage III BC found that $60 \%$ of them were $<50$ years [20]. Furthermore, in a retrospective study conducted at the 'Instituto de Enfermedades de la Mama FUCAM', a total of 68/142 (48\%) young women < 40 years were diagnosed with locally advanced disease. A total of 13 recurrences were documented in a median of 29.5 months, $92 \%$ of which were in patients with advanced stages at diagnosis [22]. Finally, results from the first 243 YWBC patients from the prospective cohort 'Joven \& Fuerte' showed that most patients had stage II (40.3\%) or stage III disease (37.9\%) [23].

Similar tendencies have been described in Brazil. In a cross-sectional study of 59,317 women using data from Brazilian hospital registries, $63 \%$ of young women < 40 years were diagnosed at advanced stages (IIB-IV). In this study, being young was associated with advanced disease at diagnosis, along with having a low level of education and living in the poorest regions [11]. Moreover, a retrospective cohort of 738 patients conducted in Brazil found stage II and stage III to be the most common stages at presentation in young women $\leq 40$ (36\% and $27 \%$, respectively) [17].

Additionally, two studies from Mexico have reported a high prevalence of genetic mutations and locally advanced disease in young patients with BC. In a prospective cohort of 190 Mexican women < 50 years with triple negative BC, the majority presented with locally advanced disease (69\%), median tumour size was $4 \mathrm{~cm}$ and a BRCA mutation was detected in $23 \%$ of patients [24]. Furthermore, a retrospective study of women $<45$ years found that $5 / 78(6.4 \%)$ had a TP53 mutation. All five patients were $<36$ years and all had locally advanced disease [25]. However, advanced presentation at early ages seems to be related not to the mutation status itself but follows the general BC presentation patterns seen in young Latin American women.

To highlight the higher advanced stages at diagnosis in Latin American countries when compared to the developed world, a comparison of stage distribution in Mexico [23], Brazil [17], Chile [16], USA [26] and New Zealand [27] is shown in Figure 2.

There are two possible explanations for younger women presenting with more advanced stage BC: 1) a biologically more aggressive tumour behaviour that leads to faster tumour growth and dissemination and 2) greater diagnosis delays among younger women. These mechanisms will be described in the following sections. 
Table 1. Studies addressing YWBC and LABC in Latin American countries.

\begin{tabular}{|c|c|c|c|c|c|}
\hline Country & Reference & Year & Main Focus & $\begin{array}{c}\text { Number of } \\
\text { patients }\end{array}$ & Conclusions \\
\hline Bahamas & K Mungre, et al [12] & 2016 & $\begin{array}{l}\text { Retrospective observa- } \\
\text { tional sociodemographic } \\
\text { description of } B C \text { in the } \\
\text { Bahamas. }\end{array}$ & 270 & $\begin{array}{l}\text { - The incidence of BC in women }<40 \text { years } \\
\text { in the Bahamas was } 9 \% \text { in the year } 2009 \text {, } \\
8 \% \text { in } 2010 \text { and } 12 \% \text { in } 2012 \text {. } \\
\text { - } 95.5 \% \text { of young patients presented with } \geq \\
\text { stage II BC. }\end{array}$ \\
\hline Brazil & Abrahao Kde, et al [11] & 2015 & $\begin{array}{l}\text { Retrospective observa- } \\
\text { tional study to analyse the } \\
\text { determinants of advanced } \\
\text { stages in Brazilian women } \\
\text { with BC. }\end{array}$ & 59,317 & $\begin{array}{l}63 \% \text { of young women }<40 \text { years were } \\
\text { diagnosed at advanced stages (IIB-IV). } \\
\text { Younger age ( } 18 \text { to } 49 \text { years old) (odds } \\
\text { ratio (OR) }=1.6195 \% \mathrm{Cl} 1.51 \text { to } 1.72 \text { ), } \\
\text { having low educational level (OR }=1.53 \\
95 \% \mathrm{Cl} 1.48 \text { to } 1.58 \text { ), living in less devel- } \\
\text { oped geographical regions (OR }=1.27 \\
95 \% \mathrm{Cl} 1.21 \text { to } 1.33 \text { ), having invasive duc- } \\
\text { tal carcinoma (OR }=2.7095 \% \mathrm{Cl} 2.56 \text { to } \\
2.84 \text { ) and invasive lobular carcinoma (OR } \\
=2.6395 \% \mathrm{Cl} 2.42 \text { to } 2.86 \text { ) were associ- } \\
\text { ated with advanced } \mathrm{BC} \text {. }\end{array}$ \\
\hline Brazil & De Lima Vazquez, et al [17] & 2016 & $\begin{array}{l}\text { Retrospective, observa- } \\
\text { tional study that compares } \\
\text { socio-demographic, clinical } \\
\text { and pathological character- } \\
\text { istics and their association } \\
\text { with long-term survival } \\
\text { between two random } \\
\text { cohorts of young ( } \leq 40 \\
\text { years) and older (50-69 } \\
\text { years) Brazilian patients } \\
\text { with BC. }\end{array}$ & 1,735 & $\begin{array}{l}\text { - Among young women }(n=469) \text {, a preva- } \\
\text { lence of } 12 \% \text { in stage I, } 43 \% \text { in stage II, } \\
32 \% \text { in stage III and } 14 \% \text { in stage IV was } \\
\text { reported. } \\
\text { - The OS rates of the two age groups were } \\
\text { similar except when analysed according to } \\
\text { treatment period (1997-2002). } \\
\text { - Although patients aged } \leq 40 \text { years har- } \\
\text { boured tumours with more aggressive clin- } \\
\text { icopathological characteristics, these were } \\
\text { not independent predictors of OS. }\end{array}$ \\
\hline Brazil & Rocha-Brischillari, et al [15] & 2017 & $\begin{array}{l}\text { Retrospective, observa- } \\
\text { tional study that analyses } \\
\text { time trends in overall } \\
\text { mortality from BC in Brazil, } \\
\text { Brazilian regions and } \\
\text { states. }\end{array}$ & 13,870 & $\begin{array}{l}\text { - New cases of BC diagnosed in advanced } \\
\text { stages continue to emerge in younger } \\
\text { women. } \\
\text { - Trend: increased mortality in all regions of } \\
\text { Brazil in women } 20-49 \text { years. }\end{array}$ \\
\hline Brazil & Schneider IJ [70] & 2009 & $\begin{array}{l}\text { Retrospective study to } \\
\text { analyse BC survival and } \\
\text { associated factors based } \\
\text { on a historical cohort of } \\
\text { women with BC diagnosis } \\
\text { from } 2000 \text { to } 2002 \text {. }\end{array}$ & 1008 & $\begin{array}{l}\text { Overall 5-year survival was } 76.2 \%(95 \% \\
\text { Cl: } 73.6-78.9) \text {. } \\
\text { Independent factors associated with } \\
\text { increased risk of death were age }<30 \\
\text { years (HR }=3.09 ; 95 \% \mathrm{Cl}: 1.25-7.67) \text {; illit- } \\
\text { eracy (HR }=3.70 ; 95 \% \mathrm{Cl}: 1.44-9.55) \text { and } \\
\text { stages III (HR =5.27; } 95 \% \mathrm{Cl}: 2.56-10.82) \\
\text { and IV (HR }=14.07 ; 95 \% \mathrm{Cl}: 6.81-29.06) \text {. } \\
\text { Young women had the worst survival rates. }\end{array}$ \\
\hline
\end{tabular}


Table 1. Continued

\begin{tabular}{|c|c|c|c|c|c|}
\hline Chile & Acevedo Francisco, et al [16] & 2015 & $\begin{array}{l}\text { Retrospective study com- } \\
\text { paring } B C \text { in young patients } \\
\text { and the elderly. }\end{array}$ & 2023 & $\begin{array}{l}\text { - Incidence between } \leq 40 \text { years and } \geq 70 \\
\text { years was, respectively: Stage I } 18.8 \% \\
\text { versus } 32.2 \% \text {, Stage II } 45 \% \text { versus } 40.1 \% \text {, } \\
\text { Stage III } 31.3 \% \text { versus } 19.9 \% \text { and Stage } \\
\text { IV } 5 \% \text { versus } 7.8 \% \text {. } \\
\text { - The younger cohort had a higher incidence } \\
\text { of triple negative ( } 17.8 \% \text { versus } 11.7 \%) \\
\text { and Luminal B ( } 43 \% \text { versus } 33.3 \%) \text { BC. } \\
\text { Young patients had a higher incidence of } \\
\text { recurrence compared to the elderly }(25.8 \\
\text { versus } 11.7 \%) \text {. }\end{array}$ \\
\hline $\begin{array}{l}\text { Latin } \\
\text { America }\end{array}$ & Villarreal-Garza, et al [1] & 2013 & $\begin{array}{l}\text { Systemic literature review } \\
\text { of BC incidence and } \\
\text { mortality among young } \\
\text { women using data from } \\
\text { the Globocan registry, and } \\
\text { related clinical, pathological } \\
\text { and survivorship aspects in } \\
\text { this region. }\end{array}$ & Not available & $\begin{array}{l}\text { - Incidence and mortality in women }<45 \\
\text { years in Latin American countries was } 20 \% \\
\text { and } 14 \% \text { versus } 12 \% \text { and } 7 \% \text { in developed } \\
\text { countries, respectively. Stage II and III dis- } \\
\text { ease, high histological grade and triple- } \\
\text { negative and HER2 BC were features } \\
\text { frequently observed among young Latin } \\
\text { American BC patients. }\end{array}$ \\
\hline Mexico & Villarreal-Garza C, et al [23] & 2017 & $\begin{array}{l}\text { Initial results of prospective } \\
\text { YWBC cohort. }\end{array}$ & 243 & $\begin{array}{l}98 \text { patients were diagnosed at stage II } \\
(40.3 \%) \text { and } 92 \text { at stage III }(37.9 \%) \text {. } \\
\text { - Nine patients ( } 4 \% \text { ) had developed distant } \\
\text { recurrences and } 12 \text { patients }(5 \%) \text { had died } \\
\text { as a consequence of BC, with a median } \\
\text { follow-up of } 17 \text { months. }\end{array}$ \\
\hline Mexico & Robles Castillo, et al [22] & 2011 & $\begin{array}{l}\text { Retrospective study that } \\
\text { determined the frequency, } \\
\text { sociodemographic, clini- } \\
\text { cal and histopathological } \\
\text { features of BC in women } \\
\text { under } 40 \text { years attending } \\
\text { a specialist breast unit in } \\
\text { Mexico City. }\end{array}$ & 142 & $\begin{array}{l}\text { - } 45.7 \% \text { were diagnosed with the early dis- } \\
\text { ease (I and IIA), } 47.89 \% \text { of cases with } \\
\text { locally advanced disease (IIB - IIIC) and } \\
9 \% \text { with metastatic disease (IV). } \\
\text { A total of } 13 \text { recurrences were docu- } \\
\text { mented; } 92 \% \text { were in patients with locally } \\
\text { advanced disease. }\end{array}$ \\
\hline Mexico & Villarreal Garza, et al [21] & 2013 & $\begin{array}{l}\text { Retrospective study that } \\
\text { described the frequency of } \\
\text { BC among young Mexican } \\
\text { patients, as well as their } \\
\text { pathological characteristics } \\
\text { at diagnosis and patterns of } \\
\text { recurrence. }\end{array}$ & 320 & $\begin{array}{l}67.5 \% \text { diagnosed with locally advanced BC. } \\
\text { - } \text { From the non-metastatic patients at diag- } \\
\text { nosis, } 31 \% \text { developed recurrence ( } 65 \% \\
\text { systemic, } 21 \% \text { loco regional and } 14 \% \text { both). } \\
\text { - After a median follow-up of } 26 \text { months, } \\
18 \% \text { of the } 320 \text { patients died secondary to } \\
\text { BC disease progression. }\end{array}$ \\
\hline Mexico & Villarreal-Garza, et al [19] & 2015 & $\begin{array}{l}\text { Retrospective study that } \\
\text { compared the recurrence- } \\
\text { free survival (RFS) among } \\
\text { neoadjuvant-treated } \\
\text { patients according to age } \\
\text { and histologic subtypes. }\end{array}$ & 3,110 & $\begin{array}{l}\text { - Young patients achieved higher pathologic } \\
\text { complete response (PCR) rates ( } 37 \% \text { ver- } \\
\text { sus } 25 \% \text { ), but the RFS interval was shorter } \\
\text { at the expense of the hormone receptor- } \\
\text { positive/HER2-negative subgroup. } \\
\text { - For patients with residual disease, young } \\
\text { age remained a significant independent } \\
\text { predictor of recurrence in patients with } \\
\text { hormone receptor-positive/HER2-negative } \\
\text { tumours but not in the HER2 positive and } \\
\text { triple negative subtypes. }\end{array}$ \\
\hline
\end{tabular}


Table 1. Continued

\begin{tabular}{|c|c|c|c|c|c|}
\hline Mexico & Villarreal-Garza, et al [18] & 2017 & $\begin{array}{l}\text { Retrospective study of a } \\
\text { single institution compar- } \\
\text { ing clinical characteristics, } \\
\text { treatment and survival } \\
\text { between women } \leq 40 \text { and } \\
>40 \text { years of age. Also, } \\
\text { survival analyses were per- } \\
\text { formed for each molecular } \\
\text { subtype. }\end{array}$ & 4315 & $\begin{array}{l}\text { - A total of } 662 \text { women (15.3\%) were } \leq 40 \\
\text { years old. Among young women, } 7.6 \% \\
\text { were diagnosed with stage I, } 33.1 \% \text { with } \\
\text { stage II, } 43.5 \% \text { with stage III and } 14.5 \text { with } \\
\text { stage IV. } \\
\text { - Younger women had more advanced dis- } \\
\text { ease, higher grade and a larger proportion } \\
\text { of luminal B and triple-negative tumours ( } P \\
<.001 \text { ). } \\
\text { - At } 5 \text { years, both DFS and OS were lower } \\
\text { in younger women, although there were no } \\
\text { differences after adjusting for stage. } \\
\text { Luminal B tumours showed a worse } 5 \text {-year } \\
\text { OS in younger women (79.1\% versus } \\
85.2 \% ; P=.03 \text { ). }\end{array}$ \\
\hline Peru & Weibin Lian [71] & 2017 & $\begin{array}{l}\text { Descriptive, retrospective } \\
\text { study that aims to compare } \\
\text { clinicopathological and } \\
\text { outcome characteristics } \\
\text { according to patient age at } \\
\text { diagnosis and menopausal } \\
\text { status. }\end{array}$ & 1024 & $\begin{array}{l}\text { - Stage III was higher in the pre versus post- } \\
\text { menopausal group ( } 33.7 \% \text { versus } 26.8 \%) \text {. } \\
\text { Premenopausal women had a lower inci- } \\
\text { dence of stage II disease ( } 48.7 \% \text { versus } \\
57.6 \%) \text {. }\end{array}$ \\
\hline
\end{tabular}

\section{More aggressive tumour behaviour and LABC among young women}

The high proportion of advanced stages at presentation seen in younger patients may be in part due to more aggressive tumour behaviour when compared to their older counterparts, as previously reported by several groups [28, 29]. YWBC tend to have large tumours with lymph node involvement, which is ultimately responsible, at least in part, for the poor prognosis seen in this population [29, 30]. Also, young women have an increased proportion of high-grade tumours and hormone receptor-negative, triple-negative and luminal B tumours, which have higher mortality at regional/distant stages than Luminal A subtypes [31]. Notably, young age seems to be particularly prognostic in women with luminal BC, which accounts for approximately $60 \%$ of tumours seen in this population [32]. Additionally, even when adjusted for clinical stage, YWBC have a worse prognosis, with higher rates of systemic relapse and lower OS than older women, which may be a consequence of tumour biology itself [28, 29]. Several studies in Latin America support this claim.

In the previously mentioned 4315-patient retrospective cohort from the INCan in Mexico, tumours in young women were more often high grade $(60.9 \%$ versus $49.6 \%, p<0.001)$, oestrogen receptor-negative $(40.5 \%$ versus $28.7 \%, p<0.001)$ and progesterone receptor-negative $(44.1 \%$ versus $36.5 \%, p<0.001)$ than patients $>40$ years. There was also a higher proportion of triple-negative BC in young women $(23 \%$ versus $14.8 \%$ ); however, there was no difference in DFS for this subtype between younger and older women. The highest difference in DFS between women $\leq 40$ years and older women was found both in Luminal A (H-score above 200$)(76.6 \%$ versus $88.2 \%, p=0.04)$ and Luminal B (H-score under 200$)$ tumours $(72.4 \%$ versus $86.2 \%, p<0.001)$ [18]. On a similar note, a prospective cohort of BC patients undergoing neoadjuvant treatment found that poor survival in young patients could be explained by the worse prognosis in the most prevalent hormone receptor-positive/HER2-negative subgroup, possibly due to a greater proportion of Luminal B tumours, tamoxifen resistance or poor adherence to hormonal treatment [19].

Furthermore, in a Brazilian retrospective cohort of $738 \mathrm{BC}$ patients, the younger group had a higher proportion of multifocal and bilateral cancer when compared with the older group ( 6.1 versus $2.5 \%, p=0.017$ and 9.8 versus $5.8 \%, p=0.037$, respectively), as well as higher frequency of low degree of differentiation and triple negative tumours (23.1 versus $16.6 \%, p=0.035$ and 10.1 versus $6.4 \% ; p=0.027)$ [17] . However, this study found no differences in OS rates between groups $(p=0.421)$.

Thus, studies from Latin American countries support the fact that more aggressive tumour characteristics are prevalent among the young BC population, which contributes to the overall burden of advanced disease $[1,7]$. 


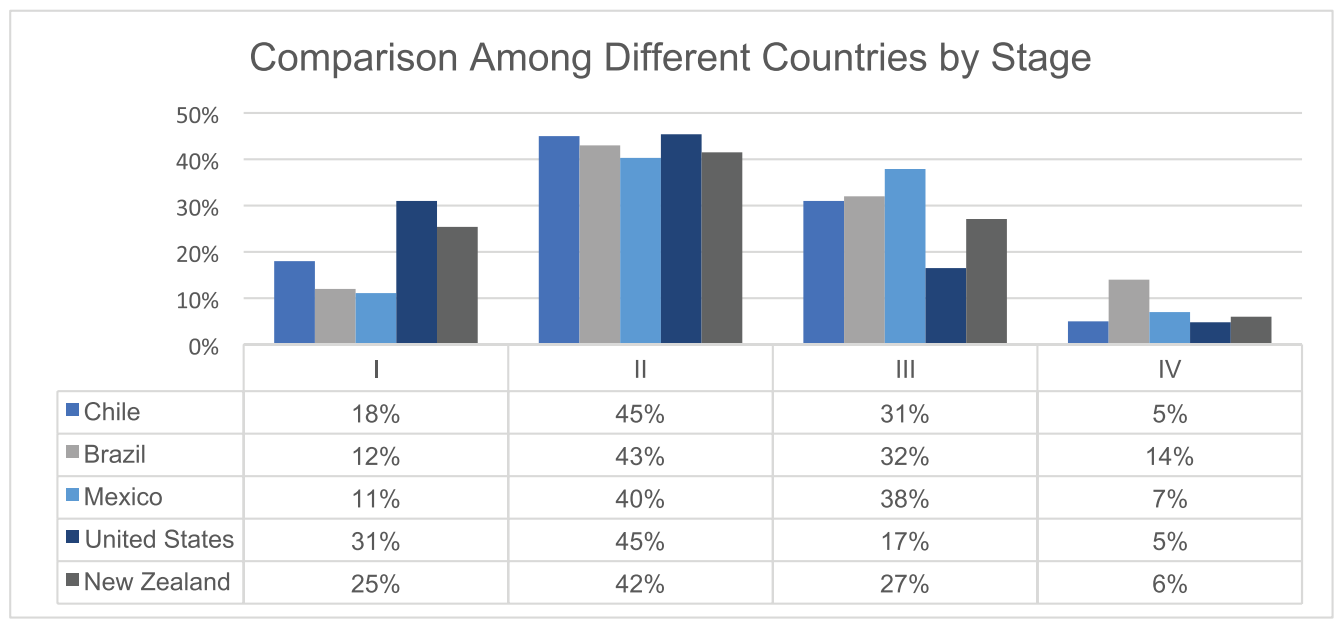

Figure 2. BC stages at diagnosis in selected countries in Latin America [16, 17, 23], USA [26] and New Zealand [27].

\section{Delays in diagnosis among young women}

The other possible explanatory mechanism of the more advanced clinical stages observed among BC in young women is that they face delays in diagnosis. Longer time intervals to initiation of care have been reported to negatively impact clinical stage and survival of BC in the general population [33,34], probably as a result of late diagnosis and delayed treatment initiation. Studies have shown that as time to care is prolonged, the probability of patients presenting at advanced stages increases [35-37]. This association between delay and survival has been shown to disappear when controlling for clinical stage [38], thus suggesting that delay is not an independent factor for a worse outcome but is linked to the advanced stage at presentation with further BC progression.

Several studies have reported greater delays in the health system interval (time from first medical consultation to treatment start) [39-41] and diagnostic interval (time from the first presentation to healthcare providers to diagnosis confirmation) [42-44] for young BC patients in comparison to their older counterparts. A similar number of studies have not confirmed an association between young age and longer health system [45] and diagnostic interval [6, 46, 47]. However, there are methodological differences between the studies that complicate their comparability.

Among the studies that confirm these associations, they all analysed only symptomatic women, most measured age either as a continuous variable [33, 41, 42] or categorised young age as being < 40 years old [44]. The only one that defined age as < 50 had a very large sample size (>9000) [39]. Therefore, the evidence available seems to favour the relationship between young age and delayed diagnosis.

As for the reviews that reported no association between young age and delay, two of them found significant crude associations that then disappeared when controlling by symptom presentation [6,47], menstrual status [47] and history of benign breast conditions [47], which are all related with young age. The remaining negative studies defined young age as $<50$ years, had a small sample size $(n=380)$ or focused on women identified through screening mammography [48], which could be the reasons they did not find a significant association between age and delay. It could also be that this relationship is different in diverse health system contexts.

On the other hand, only three quality studies have analysed the effect of young age on the treatment interval (time between diagnosis confirmation and cancer treatment initiation) and also showed contradictory results. One found an increased risk of delayed treatment among younger women [49], another reported a decreased risk in this group [46] and the last one found no association [48]. 
There are very few studies reporting BC time intervals of care in Latin America and even fewer that focus on the health system or diagnostic intervals [50-54]. Table 2 summarizes findings and main characteristics of these studies. Most studies report very long diagnostic intervals, with the shortest median reported at 3 months in the Colombian study [50]. These delays are most likely a consequence of the inequitable availability and quality of cancer services, including healthcare personnel, infrastructure and diagnostic equipment, which make access to cancer care across Latin American countries challenging [55].

Unfortunately, none of the Latin American studies of time intervals for BC care focus on the relationship between age and the length of the health system or diagnostic intervals. Nevertheless, several studies included age in their multivariate analyses but did not find significant associations. However, it is interesting to note that one study identified mechanisms that explain diagnosis delay among BC patients in Mexico City [56]. In this report, perceived medical errors in primary care services were significantly associated with longer diagnostic intervals and young age, as well as symptomatic presentation. Furthermore, a recent study that evaluated BC knowledge among general physicians in Mexico found very low levels of knowledge about screening recommendations [57].

In conclusion, although evidence that supports an association between age and diagnosis delay is scarce, it can be hypothesised that young age conveys a higher risk of diagnosis delay due to: 1) a greater difficulty for both patients and physicians to suspect BC in this low cancer-risk group, 2) the common occurrence of benign breast conditions in younger women and 3) the fact that screening mammography is not useful for women $<40$ years of age.

\section{Burden of advanced disease in young women}

Burden of disease derives not only from the high morbidity and mortality rates encountered in YWBC, but also on the profound and lasting effects on self-development, family dynamics, social and professional lives [7, 58]. Particularly challenging age-related issues associated with early and long-term morbidity include: chemotherapy-induced premature ovarian failure, infertility, body image disturbance and compromised sexual function, among others [7, 8]. As a notable example, initial results from the Mexican 'Joven \& Fuerte' cohort of YWBC showed significant morbidity at the time of diagnosis and worsening at 6-month follow-up. Mexican women have shown high rates of sexual dysfunction at baseline and 6 months $(61.4 \%$ and $74.3 \%$, respectively, $p<0.001)$, as well as an elevated proportion of low sexual satisfaction at both moments $(40.6 \%$ and $43.5 \%, p=0.004)$ [23]. Furthermore, Mexican YWBC experience significant deterioration in many quality of life domains during the first year of follow-up, with a marked decrease at 6 months [59]. Conversely, emotional functioning and future perspective improved over time [59].

Table 2. Health system intervals reported for Latin American countries.

\begin{tabular}{|c|c|c|c|c|c|}
\hline Reference & $\mathbf{n}$ & $\begin{array}{c}\text { Median } \\
\text { patient age }\end{array}$ & $\begin{array}{c}\text { Health services interval } \\
\text { measured }\end{array}$ & $\begin{array}{l}\text { Median } \\
\text { interval }\end{array}$ & $\begin{array}{l}\% \text { LABC } \\
\text { patients }\end{array}$ \\
\hline \multicolumn{6}{|l|}{ Brazil } \\
\hline Rezende, 2009 [52] & 104 & 54 & Diagnostic interval & $6.5 \mathrm{mo}$ & $37.5 \%$ II \& III \\
\hline Barros, 2013 [54] & 250 & 52 & Health system interval & $5.2 \mathrm{mo}$ & $74.5 \%$ II \& III \\
\hline \multicolumn{6}{|l|}{ Colombia } \\
\hline \multirow{2}{*}{ Piñeros, 2011 [50] } & \multirow{2}{*}{1106} & \multirow{2}{*}{53.1} & Diagnostic interval & $3 \mathrm{mo}$ & \multirow{2}{*}{$45 \%$ LABC } \\
\hline & & & Health system interval & $4.6 \mathrm{mo}$ & \\
\hline \multicolumn{6}{|l|}{ Mexico } \\
\hline Bright, 2011 [53] & 32 & 53 & Diagnostic interval & $6.6 \mathrm{mo}$ & $70 \%$ LABC \\
\hline Unger-Saldaña, 2015 [37] & 597 & 51 & Diagnostic interval & $4.2 \mathrm{mo}$ & $67 \%$ II \& III \\
\hline Angeles-Llerenas, 2016 [51] & 854 & 52 & Mammography result to treatment & $2.2 \mathrm{mo}$ & $79.8 \%$ II \& III \\
\hline
\end{tabular}


Moreover, in Latin American countries, where there is a predominant lack of financial resources across the region, YWBC face extra challenges to access supportive medical interventions that are not routinely covered. For example, in a cross-sectional study involving 134 newly diagnosed young Mexican BC patients, although $48 \%$ reported a willingness to have children prior to BC diagnosis, only $3 \%$ considered that they could afford extra expenses [23]. In comparison, $50 \%$ to $60 \%$ of young BC patients in the USA feel financially comfortable/ can afford 'special things' [60, 61].

Additionally, BC has a strong economic impact, especially in young patients, as the majority of women $<54$ years are economically active [62] and prolonged sick leave can cause financial difficulties and emotional distress [63]. An observational study in a third-level hospital in Brazil evaluating return to work rates in BC patients 18-57 years old found that although $61.5 \%$ received support from their employers, only $29.1 \%$ reported adjustment offering so that they could keep working during treatment [63]. Overall, $22.1 \%$ and $28.8 \%$ of patients had returned to work at 6 and 12 months after $B C$ diagnosis, respectively.

The burden of $\mathrm{BC}$ can be objectively described in terms of disability-adjusted life years (DALYs), a measure that combines years of potential life lost to premature mortality and years of productive life lost due to disability. Overall, a total of 613,000 DALYs are lost in Latin American countries due to BC [64]. Although the general social burden is lower than in developed countries, where incidence rates of BC are highest, the proportion of losses due to mortality is greater in Latin America as a consequence of higher mortality rates and younger age of women at diagnosis [64].

Young age at diagnosis and death entails a heavy burden in countries like Brazil, Peru and Mexico [64]. In Brazil, for example, DALYs lost per 100,000 women are nearly double compared to most countries in the region, which might be explained by the increasing BC incidence and mortality in young women $<40$ years, as well as, an increasing number of diagnoses in working-age women which greatly contributes to lost years. Likewise, in Mexico, significant productivity losses occur due to the young age at diagnosis and death.

\section{Key intervention strategies}

Due to the high prevalence of $\angle A B C$ in young women in Latin America and the burden of disease, this issue deserves significant attention since its diagnosis requires high clinical suspicion [17]. Because data in Latin America has shown that $90 \%$ of BCs in young women are self-detected [65] and routine mammography screening is not recommended for this age group, it is imperative to dedicate resources for general public education about the possibility of a malignant diagnosis in young women. Also, healthcare providers should be sensitive to the current YWBC standpoint and not automatically discard this diagnostic possibility because of young age. Furthermore, it is equally important to educate patients and caregivers about the presence of hereditary cancer risk factors and promptly refer high-risk patients to genetic counselling. If young mutation carriers were regularly identified, timely preventive measures could be implemented and earlier detection of $\mathrm{BC}$ achieved.

Early diagnosis strategies could be especially useful among young women living in Latin America, which comprises mainly low and middleincome countries that lack population-based BC screening programmes. These strategies should include interventions directed to: 1) improve BC awareness among the population at risk, particularly of red flag breast symptoms, relevance of prompt medical attention seeking and available health services; 2) strengthen local health systems capacity to achieve a prompt and accurate diagnosis (e.g. primary care, breast imaging diagnostic services, pathology facilities) and 3) improve timely access to quality treatment (e.g. making treatment accessible without cost for the most vulnerable, developing shorter referral routes).

Examples of early diagnosis strategies that are currently underway are encouraging. Preliminary findings of a randomised controlled study from the Cairo Breast Screening trial demonstrated that screening based on breast self-examination combined with clinical evaluation resulted in downstaging of tumours in the intervention arm compared with the control arm [66]. Remarkably, the Mexican navigation programme 'Alerta Rosa', which focused in prioritising and navigating symptomatic patients and those with abnormal breast findings for prompt diagnosis and treatment initiation, proved effective in reducing health system delays, with a median of 33 days from the first contact to treatment initiation [67]. This programme is currently ongoing, with the ultimate goal of BC downstaging, thorough its gradual implementation across the country [68].

Finally, as YWBC have an added load of unique concerns, comprehensive programmes have been created worldwide, predominantly in the USA and Canada [7, 8, 69]. However, in limited-resource settings, cancer-control efforts are predominantly aimed at improving medical care, while supportive care and survivorship issues are not highly prioritised and often neglected. Considerable morbidity due to advanced 
disease and aggressive treatment, coupled with a lack of support services and financial limitations, greatly undermine patients' quality of life in Latin American countries [1]. Thus, models of supportive care should be implemented for this particular group of patients to provide better care for this emergent challenge. In 2014, the first dedicated programme for the care of young BC patients in Latin America was implemented. 'Joven \& Fuerte: Programme for Young Women with Breast Cancer in Mexico' aims to optimise young patients' clinical and psychosocial care, enhance education regarding their special needs and promote targeted research [23]. To date, this programme has provided care for up to 500 patients and seeks to promote its replication in other health care centres across Mexico and Latin America.

\section{Conclusion}

The data presented urges Latin American countries to consider dedicating resources to enhance earlier diagnosis and prompt referrals of YWBC. Special efforts are needed for younger women, as mammography screening is not recommended in this population. Additionally, more research is required in Latin America regarding the prevalence and outcomes of $\mathrm{BC}$ in young women, its biological characteristics and reasons for diagnosis and treatment delays. Finally, supportive care programmes for YWBC should be implemented, as a means of improving patients' and their families' well-being.

\section{Conflicts of interest}

The authors certify that they have no affiliations with or involvement in any organisation or entity with any financial interest or non-financial interest in the subject matter or materials discussed in this manuscript.

\section{Funding}

The authors received no specific funding for this work.

\section{References}

1. Villarreal-Garza C, Aguila C, and Magallanes-Hoyos MC, et al (2013) Breast cancer in young women in Latin America: an unmet, growing burden Oncologist 18(12) 1298-1306 https://doi.org/10.1634/theoncologist.2013-0321 PMID: 24277771 PMCID: 3868424

2. Knaul FM, Nigenda G, and Lozano R, et al (2008) Breast cancer in Mexico: a pressing priority Reprod health matters 16(32) 113-123 https://doi.org/10.1016/S0968-8080(08)32414-8 PMID: 19027629

3. Knaul FM, Bhadelia A, and Gralow J, et al (2012) Meeting the emerging challenge of breast and cervical cancer in low- and middle-income countries Inter j gynaecol and obstetrics: the official organ of the Inter Feder of Gynaecol and Obstetrics 119(1) S85S88 https://doi.org/10.1016/j.ijgo.2012.03.024 PMID: 22883910

4. Ferlay J, Soerjomataram I, and Ervik M, et al (2013) GLOBOCAN 2012 v1.0, Cancer incidence and mortality worldwide: IARC cancerBase No. 11 [Lyon, France: International Agency for Research on cancer]. [http://globocan.iarc.fr/]

5. Collins LC, Marotti JD, and Gelber S, et al (2012) Pathologic features and molecular phenotype by patient age in a large cohort of young women with breast cancer Breast cancer res and treat 131(3) 1061-1066 https://doi.org/10.1007/s10549-011-1872-9

6. Partridge AH, Hughes ME, and Ottesen RA, et al (2012) The effect of age on delay in diagnosis and stage of breast cancer Oncologist 17(6) 775-782 https://doi.org/10.1634/theoncologist.2011-0469 PMID: 22554997 PMCID: $\underline{3380876}$

7. Partridge AH, Ruddy KJ, and Kennedy J, et al (2012) Model program to improve care for a unique cancer population: young women with breast cancer J Oncol Pract 8(5) e105-e110 https://doi.org/10.1200/JOP.2011.000501 PMCID: 3439235

8. Ali A and Warner E (2013) Pynk: breast cancer program for young women Current Oncol 20(1) e34-e39 https://doi.org/10.3747/ $\underline{\text { co.20.1131 }}$ 
9. Franco-Marina F, Lopez-Carrillo L, and Keating NL, et al (2015) Breast cancer age at diagnosis patterns in four Latin American Populations: a comparison with north american countries Cancer Epidemiol 39(6) 831-837 https://doi.org/10.1016/j. canep.2015.10.004 PMID: 26651442

10. Rodriguez-Cuevas S, Macias CG, and Franceschi D, et al (2001) Breast carcinoma presents a decade earlier in mexican women than in women in the united states or european countries Cancer 91(4) 863-868 PMID: 11241256

11. Abrahao Kde S, Bergmann A, and Aguiar SS, et al (2015) Determinants of advanced stage presentation of breast cancer in 87,969 Brazilian women Maturitas 82(4) 365-370 https://doi.org/10.1016/j.maturitas.2015.07.021 PMID: 26358931

12. Mungrue $\mathrm{K}$, Chase $\mathrm{H}$, and Gordon J, et al (2016) Breast cancer in the bahamas in 2009-2011 Breast Cancer (Auckl) $1045-52$

13. Haddad N and Silva MBD (2000) Mortalidade feminina em idade reprodutiva no Estado de São Paulo, Brasil, 1991-1995: causas básicas de óbito e mortalidade materna Revista de Saúde Pública 34 64-70 https://doi.org/10.1590/S0034-89102000000100012

14. INEGI (2018) Estadísticas a propósito del día mundial contra el cáncer (4 de febrero) Comunicado De Prensa 61(81) 13

15. Rocha-Brischiliari SC, Oliveira RR, and Andrade L, et al (2017) The rise in mortality from breast cancer in young women: trend analysis in Brazil PLoS One 12(1) e0168950 https://doi.org/10.1371/journal.pone.0168950 PMID: 28046087 PMCID: $\underline{5207532}$

16. Acevedo F, Camus M, and Sanchez C (2015) Breast cancer at extreme ages-a comparative analysis in chile Asian Pac J Cancer Pre 16(4) 1455-1461 https://doi.org/10.7314/APJCP.2015.16.4.1455

17. De Lima Vazquez F, Silva TB, and Da Costa Vieira RA, et al (2016) Retrospective analysis of breast cancer prognosis among young and older women in a Brazilian cohort of 738 patients, 1985-2002 Oncol Lett 12(6) 4911-4924 https://doi.org/10.3892/ ol.2016.5360

18. Villarreal-Garza C, Mohar A, and Bargallo-Rocha JE, et al (2017) Molecular subtypes and prognosis in young mexican women with breast cancer Clin Breast Cancer 17(3) e95-e102 https://doi.org/10.1016/j.clbc.2016.11.007 PMID: 28065398

19. Villarreal-Garza CM, Arce-Salinas C, and Lasa F, et al (2015) Outcome of neoadjuvant-treated young patients with hormone receptor-positive breast cancer J Clin Oncol 33(15) e11577

20. Rodríguez-Cuevas SHB, Labastida AS (1997) Tratamiento de las etapas III del cáncer de mama Cirugia General $19211-215$

21. Villarreal-Garza C, Hoyos C, and Meza-Herrera V, et al (2013) Abstract P5-12-10: pathological characteristics and patterns of recurrence and mortality among young Mexican breast cancer patients Cancer Research 73 P5-12-10-P5-12-10. https://doi. org/10.1158/0008-5472.SABCS13-P5-12-10

22. Robles-Castillo J, Ruvalcaba-Limon E, Maffuz A, and Rodriguez-Cuevas S (2011) Cáncer de mama en mujeres mexicanas menores de 40 años Ginecol Obstet Mex 79(8) 482-488 PMID: $\underline{21966845}$

23. Villarreal-Garza C, Castro-Sanchez A, and Platas A, et al (2017) Joven and Fuerte: program for young women with breast cancer in Mexico-initial results Revista de investigacion Clinica 69(4)

24. Villarreal-Garza CM, Weitzel JN, and Sifuentes E, et al (2014) Founder effect and a high prevalence of BRCA1 mutations among young Mexican triple-negative breast cancer (TNBC) patients J Clin Oncol 32(15) 1522

25. Gallardo LN, Tusie-Luna T, and Tusie-Luna MI, et al (2016) TP53 germline mutations in young females with early onset breast cancer in a Mexican population J Clin Oncol 34(15) e13027 https://doi.org/10.1200/JC0.2016.34.15 suppl.e13027

26. Zimmer AS, Zhu K, and Steeg PS, et al (2018) Analysis of breast cancer in young women in the Department of Defense (DOD) database Breast cancer research and treatment 168(2) 501-511 https://doi.org/10.1007/s10549-017-4615-8 PMCID: 6301053

27. Seneviratne S, Lawrenson R, and Harvey V, et al (2016) Stage of breast cancer at diagnosis in New Zealand: impacts of sociodemographic factors, breast cancer screening and biology BMC cancer 16129 https://doi.org/10.1186/s12885-016-2177-5 PMID: 26896237 PMCID: 4 761194 
28. Han W, Kim SW, and Ae Park I, et al (2004) Young age: an independent risk factor for disease-free survival in women with operable breast cancer BMC cancer 4(1) 82 https://doi.org/10.1186/1471-2407-4-82 PMID: 15546499 PMCID: 545947

29. Bleyer A, Barr R, and Hayes-Lattin B, et al (2008) The distinctive biology of cancer in adolescents and young adults Nature reviews Cancer 8(4) 288-298 https://doi.org/10.1038/nrc2349 PMID: 18354417

30. Azim HA and Partridge AH (2014) Biology of breast cancer in young women Breast Cancer Research: BCR 16427 https://doi. org/10.1186/s13058-014-0427-5 PMID: 25436920 PMCID: 4303229

31. Ortiz AP, Frías O, and Pérez J, et al (2013) Breast cancer molecular subtypes and survival in a hospital-based sample in puerto rico Cancer Medicine 2(3) 343-350 https://doi.org/10.1002/cam4.78 PMID: 23930211 PMCID: 3699846

32. Partridge $\mathrm{AH}$, Hughes $\mathrm{ME}$, and Warner $\mathrm{ET}$, et al (2016) Subtype-dependent relationship between young age at diagnosis and breast cancer survival J Clin Oncol 34(27) 3308-3314 https://doi.org/10.1200/JC0.2015.65.8013 PMID: 27480155

33. Neal RD, Tharmanathan $\mathrm{P}$, and France $\mathrm{B}$, et al (2015) Is increased time to diagnosis and treatment in symptomatic cancer associated with poorer outcomes? Systematic review Br J Cancer 112(1) S92-S107 https://doi.org/10.1038/bjc.2015.48 PMID: 25734382 PMCID: $\underline{4385982}$

34. Richards MA, Westcombe AM, and Love SB, et al (1999) Influence of delay on survival in patients with breast cancer: a systematic review Lancet 353(9159) 1119-1126 https://doi.org/10.1016/S0140-6736(99)02143-1 PMID: 10209974

35. Ermiah E, Abdalla F, and Buhmeida A, et al (2012) Diagnosis delay in libyan female breast cancer BMC research notes 5452 https://doi.org/10.1186/1756-0500-5-452 PMID: 22909280 PMCID: 3542159

36. Warner ET, Tamimi RM, and Hughes ME, et al (2012) Time to diagnosis and breast cancer stage by race/ethnicity Breast cancer res and treat 136(3) 813-821 https://doi.org/10.1007/s10549-012-2304-1

37. Unger-Saldaña K, Miranda A, and Zarco-Espinoza G, et al (2015) Health system delay and its efect on clinical stage of breast cancer: multicenter study Cancer 2198-2206 https://doi.org/10.1002/cncr.29331

38. Richards MA, Smith P, and Ramirez AJ, et al (1999) The influence on survival of delay in the presentation and treatment of symptomatic breast cancer Br J Cancer 79(5-6) 858-864 https://doi.org/10.1038/sj.bjc.6690137 PMID: 10070881 PMCID: 2362673

39. Sainsbury R, Johnston C, and Haward B (1999) Effect on survival of delays in referral of patients with breast-cancer symptoms: a retrospective analysis Lancet 353(9159) 1132-1135 https://doi.org/10.1016/S0140-6736(99)02374-0 PMID: 10209976

40. Montella M, Crispo A, and D'Aiuto G, et al (2001) Determinant factors for diagnostic delay in operable breast cancer patients Europ J Can Prev 10(1) 53-59 https://doi.org/10.1097/00008469-200102000-00006

41. Robertson R, Campbell NC, and Smith S, et al (2004) Factors influencing time from presentation to treatment of colorectal and breast cancer in urban and rural areas Br J Cancer 90(8) 1479-1485 https://doi.org/10.1038/sj.bjc.6601753 PMID: 15083172 PMCID: 2409724

42. Barber MD, Jack W, and Dixon JM Diagnostic delay in breast cancer Br J Surg 91(1) 49-53 PMID: 14716793

43. Neal RD and Allgar VL (2005) Sociodemographic factors and delays in the diagnosis of six cancers: analysis of data from the National Survey of NHS Patients: Cancer Br J Cancer 92(11) 1971-1975 https://doi.org/10.1038/sj.bjc.6602623 PMID: 15900296 PMCID: 2361785

44. Stuver SO, Zhu J, and Simchowitz B, et al (2011) Identifying women at risk of delayed breast cancer diagnosis Jt Comm J Qual Patient Saf 37(12) 568-575 https://doi.org/10.1016/S1553-7250(11)37073-0

45. Arndt V, Sturmer T, and Stegmaier C, et al (2003) Provider delay among patients with breast cancer in Germany: a populationbased study J Clin Oncol 21(8) 1440-1446 https://doi.org/10.1200/JC0.2003.08.071 PMID: 12697864

46. Molinie F, Leux C, and Delafosse $P$, et al (2013) Waiting time disparities in breast cancer diagnosis and treatment: A populationbased study in France Breast 22(5) 810-816 https://doi.org/10.1016/j.breast.2013.02.009 PMID: 23473773 
47. Huo Q, Cai C, and Zhang Y, et al (2015) Delay in diagnosis and treatment of symptomatic breast cancer in China Ann Surg Oncol 22(3) 883-888 https://doi.org/10.1245/s10434-014-4076-9

48. Khanna S, Kim KN, and Qureshi MM, et al (2017) Impact of patient demographics, tumor characteristics, and treatment type on treatment delay throughout breast cancer care at a diverse academic medical center Int J Womens Health 9 887-896 https:// doi.org/10.2147/IJWH.S150064 PMID: 29255374 PMCID: $\underline{5723124}$

49. McGee SA, Durham DD, and Tse CK, et al (2013) Determinants of breast cancer treatment delay differ for African American and White women Cancer Epidemiol Biomarkers Prev 22(7) 1227-1238 https://doi.org/10.1158/1055-9965.EPI-12-1432 PMID: 23825306 PMCID: $\underline{3719384}$

50. Pineros M, Sanchez R, and Perry F, et al (2011) Delay for diagnosis and treatment of breast cancer in Bogota, Colombia Salud publica de Mexico 53(6) 478-485

51. Angeles-Llerenas A, Torres-Mejia G, and Lazcano-Ponce E, et al (2016) Effect of care-delivery delay on the survival of Mexican women with breast cancer Salud publica de Mexico 58(2) 237-250 https://doi.org/10.21149/spm.v58i2.7793 PMID: 27557382

52. Rezende MC, Koch HA, and Figueiredo Jde A, et al (2009) Factors leading to delay in obtaining definitive diagnosis of suspicious lesions for breast cancer in a dedicated health unit in Rio de Janeiro Revista brasileira de ginecologia e obstetricia: revista da Federacao Brasileira das Sociedades de Ginecologia e Obstetricia 31(2) 75-81 PMID: 19407912

53. Bright $\mathrm{K}$, Barghash $\mathrm{M}$, and Donach $\mathrm{M}$, et al (2001) The role of health system factors in delaying final diagnosis and treatment of breast cancer in Mexico City, Mexico Breast 20(2) S54-S59 https://doi.org/10.1016/j.breast.2011.02.012

54. Barros ÂF, Uemura G, and Macedo JLSD (2013) Tempo para acesso ao tratamento do câncer de mama no Distrito Federal, Brasil Central Revista Brasileira de Ginecologia e Obstetrícia 35 458-463 https://doi.org/10.1590/S0100-72032013001000006

55. Goss PE, Lee BL, and Badovinac-Crnjevic T, et al (2013) Planning cancer control in Latin America and the Caribbean Lancet Oncol 14(5) 391-436 https://doi.org/10.1016/S1470-2045(13)70048-2 PMID: 23628188

56. Unger-Saldana K, Ventosa-Santaularia D, and Miranda A, et al (2018) Barriers and explanatory mechanisms of delays in the patient and diagnosis intervals of care for breast cancer in Mexico Oncologist 23(4) 440-453 https://doi.org/10.1634/theoncologist.2017-0431

57. Ortega-Olvera C, Torres-Mejia G, and Sanchez-Zamorano LM, et al (2016) Knowledge and recommendations regarding breast cancer early screening in an upper middle income country: Primary and secondary health care professionals Prev Med 86 147-152 https://doi.org/10.1016/i.ypmed.2016.02.041 PMID: 26944518

58. Villarreal-Garza CC-SA (2017) Preface Revista de Investigación Clínica 69(4) 179-180

59. Villarreal-Garza C, Platas A, and Miaja M, et al (2018) Changes in quality of life at baseline, 6, and 12-months of the "Joven y fuerte" prospective cohort pilot phase (ASCO Meetings, in press)

60. Partridge AH, Gelber S, and Peppercorn J, et al (2004) Web-based survey of fertility issues in young women with breast cancer J Clin Oncol 22(20) 4174-4183 https://doi.org/10.1200/JCO.2004.01.159 PMID: 15483028

61. Ruddy KJ, Gelber SI, and Tamimi RM, et al (2014) Prospective study of fertility concerns and preservation strategies in young women with breast cancer J Clin Oncol 32(11) 1151-1156 https://doi.org/10.1200/JCO.2013.52.8877 PMID: 24567428 PMCID: $\underline{4164759}$

62. Novta N (2017) Women at work in Latin America and the caribbean ed Novta N (Washington, DC: International Monetary Fund)

63. Landeiro L, Fraile N, and Fede A, et al (2017) Abstract P4-19-06: Return to work after breast cancer diagnosis: An observational prospective study of 125 patients in South America Cancer Research 77 P4-19-06-P4-19-06. https://doi.org/10.1158/1538-7445. SABCS16-P4-19-06 
64. Justo N, Wilking N, and Jonsson B, et al (2013) A review of breast cancer care and outcomes in Latin America Oncologist 18(3) 248-256 https://doi.org/10.1634/theoncologist.2012-0373 PMID: 23442305 PMCID: 3607519

65. Castro-Sanchez A, Barragan-Carrillo R, and Miaja M, et al (2018) Abstract P4-10-09: Delay in diagnosis of breast cancer in Mexican young women: Report of the "Joven y Fuerte" prospective cohort pilot phase Cancer Research 78(4) P4-10-09 https://doi. org/10.1158/1538-7445.SABCS17-P4-10-09

66. Boulos S, Gadallah M, and Neguib S, et al (2005) Breast screening in the emerging world: high prevalence of breast cancer in Cairo Breast 14(5) 340-346 https://doi.org/10.1016/j.breast.2005.07.002 PMID: 16131468

67. Villarreal-Garza C, Mireles-Aguilar A, and Tamez-Salazar J (2018) "Alerta Rosa" breast cancer navigation program in Mexico: initial results and plan of action (ASCO Meetings, in press)

68. Mireles-Aguilar T, Tamez-Salazar J, and Muñoz-Lozano JF, et al (2018) "Alerta Rosa": Novel alert and navigation program in Nuevo Leon, Mexico for reducing health system interval delays (UICC, in press)

69. Villarreal-Garza C, Martinez-Cannon BA, and Platas A, et al (2015) Specialized programs to support young women with breast cancer Curr Opin Support Palliat Care 9(3) 308-316 https://doi.org/10.1097/SPC.0000000000000155 PMID: 26125308

70. Schneider IJC and d'Orsi E (2009) Sobrevida em cinco anos e fatores prognósticos em mulheres com câncer de mama em Santa Catarina, Brasil Cadernos de Saúde Pública 25 1285-1296 https://doi.org/10.1590/S0102-311X2009000600011

71. Lian W, Fu F, and Lin Y, et al (2017) The Impact of Young Age for Prognosis by Subtype in Women with Early Breast Cancer Scientific Reports 7(1) 11625 https://doi.org/10.1038/s41598-017-10414-x PMID: 28912475 PMCID: $\underline{599495}$ 